\title{
Post-print version:
}

García-Espinel, J. D., Alvarez-García-Lubén, R., González-Herrero, J. M., \& Castro-Fresno, D. (2016). Design and construction methods of caisson-type maritime infrastructures using GFRP. Journal of Composites for Construction, 20(1) doi: 10.1061/(ASCE)CC.1943-5614.0000591

\section{Design and Construction Methods of Caisson-Type Maritime Infrastructures Using GFRP}

\author{
J.D. Garcia-Espinel1; ; R. Alvarez-Garcia-Luben²;
}

J.M. Gonzalez-Herrero ${ }^{3}$; D. Castro-Fresno 4

(1) José Daniel García-Espinel

Civil engineer PhD student - Universidad de Cantabria, Spain

\& Technology Transfer Manager of Innovation Division. ACCIONA S.A

Av.Europa 18, 28108 Alcobendas, Madrid, Spain

Email: josedaniel.garcia.espinel@acciona.com

(2) Ricardo Alvarez García-Lubén

Civil engineer \& Innovation Manager, ACCIONA INGENIERIA

Anabel Segura, 11, Centro Empresarial Albatros, Edificio D, 28108 Alcobendas, Madrid, Spain

Email: ricardo.alvarez.garcialuben@acciona.com

(3) José Manuel González-Herrero

Civil engineer \& Head of the Water and Environment Area, ACCIONA INGENIERIA 
Anabel Segura, 11, Centro Empresarial Albatros, Edificio D, 28108 Alcobendas, Madrid, Spain

Email: josemanuel.gonzalez.herrero@acciona.com

(4) Daniel Castro-Fresno

Technical Director of GITECO Research Group. Universidad de Cantabria.

Avda. De los Castros, s/n. 39005 Santander, Spain.

Corresponding author: castrod@unican.es

\begin{abstract}
Glass fiber-reinforced polymers (GFRPs) are commonly used in various applications in civil engineering projects. However, they are not common in the construction of civil marine structures. GFRP caisson technology was developed for the construction of two mooring dolphins in Puerto el Rosario (Fuerteventura, Spain). UV-protected glass fiber and epoxy resin coats were used to build a $12 \mathrm{~m}$ diameter, $13.3 \mathrm{~m}$ high cylindrical structure. A finite element model was used to verify the sandwich composite configuration using the Tsai-Hill criteria - the shear strength of the skins and honeycomb core and the buckling and local failure modes with respect to the composite configuration. This is the first time that the two caissons were designed and built of polymeric materials and installed in a seaport. Accordingly, the construction technique marks a milestone in civil engineering because of its highly innovative nature and because it will significantly reduce the time associated with and the complexity of construction operations.
\end{abstract}


Keywords: Caisson, glass, epoxy, GFRP, mooring, dolphin.

\section{INTRODUCTION}

Currently, two main techniques are used to build docking infrastructures for ships - sloped or vertical concrete breakwater structures. The principal materials used are rocks and earth extracted from a quarry for the sloped structures and concrete for the vertical breakwater structures. Concrete caissons are gravity structures of vertical walls made of concrete used to build sea infrastructures where ships can be docked. Caissons could be used to build a pier if several of them are placed together or as mooring dolphins if they are separated, thus enlarging an existing pier to add more mooring points for ships. Countries where vertical concrete breakwaters are more common include Italy (Franco 1994), Spain and Japan. Sloped breakwaters are commonly used throughout the world. Both techniques have advantages and disadvantages according to Recommendations for Maritime Works (Puertos del Estado [PE], 2008). Sloped breakwater structures are environmentally more aggressive, as they require large amounts of raw materials be extracted from nearby quarries. They also have a strong impact on sea-floor wildlife, as they require considerably more area than the concrete-type structures (Frihy, 2001). Accordingly, concrete-type structures cause less damage to the sea floor. However, one of the disadvantages of concrete-type structures is that they require skilled technicians and advanced machinery for their operations. This machinery, which is generally placed in the harbor, affects port operations. Moreover, the environmental impact of this strategy is important because the manufacturing of concrete requires crushed rocks and sand 
to be extracted from a quarry, thus placing a heavy demand on energy use. Given all of these issues, it appears evident that a new construction strategy for building docks in seaports using caisson-type solutions that are environmentally friendly and less intrusive on port operations should be developed. Consistent with this new thinking, structures have been developed using glass/epoxy composite rather than concrete and pre-fabricated elements that have to be assembled on site. This new construction technique is relevant in civil engineering because of its highly innovative nature and because it significantly reduces both the time and complexity of construction operations.

\section{State-of-the-art}

The use of fiber-reinforced polymer (FRP) composites in the construction of civil infrastructures has increased during the last two decades in Spain. Bridge construction using FRP composites is well known. The most representative examples are in the Province of Asturias (Spain), where a 10-m span carbon fiber composite highway bridge was constructed in 2004 (Mieres et al., 2006) and the M-111 highway in the Province of Madrid, Spain, where two 14-m span twin carbon fiber composite highway bridges were constructed in 2007 (Garcia-Espinel \& Del Amo-Sanz, 2010). In the USA, the most representative FRP road bridges are the 57-m County Line Road Bridge over Ohio's Tiffin River, which was built in 2003, and Ohio's 67-m Fairgrounds Road Bridge, which was built in 2002 (Creese \& Gangarao 2004, p.107). Built in 1990 in the UK and having a 63-m main span, the Aberfeldy, the world's first major advanced composite footbridge, is the most representative GFRP composite pedestrian footbridge (Potyrała, 2011). With a 12-m main span and a length of 80 m, the River Leri Footbridge, built in 2009 in the UK, 
is another representative GFRP footbridge (Strongwell 2009, 'Leri footbridge built with Strongwell's lightweight, corrosion resistant FRP', para. 1). The most recently constructed GFRP composite footbridge is the Ooypoort Bridge. With its 56-m span, this footbridge, which was built in the Netherlands in 2014 , is the longest single-span composite footbridge in the world (Delf Infra Composites 2014, 'Bridges and bridge decks with composites', para. 1). FRP composites have also been used to build long pedestrian footbridges, such as a stress-ribbon footbridge in the Province of Cuenca in Spain (Garcia-Espinel et al., 2012). This bridge, which is $217 \mathrm{~m}$ long and has a 70-m span, consists of a $25 \mathrm{~cm}$ thick concrete slab supported by CFRP cables. Moreover, FRP composites have been used to reinforce damaged structures, such as bridge piers (Hoshikuma et al., 1997), and GFRP bars have been used as alternatives to steel reinforcements to reinforce concrete (Benmokrane et al., 1995).

Despite the numerous examples cited herein, however, there are limited examples of GFRP materials being used in maritime civil engineering constructions. The few references to composite elements built for seashore protection against the impact of waves include the Tuapse-Adler railway on the Russian Black Sea Coast (Ashpizet al., 2010). There are also some examples of composite piles being used for mooring ships, such as the 190 GFRP piles that measure $14.3 \mathrm{~m}$ in length and $30.5 \mathrm{~cm}$ in diameter (Creative Pultrusions 2011, 'San Francisco West Harbor Renovation Project. San Francisco CA.', para.1). Another application is the use of reinforced composite sheet pilings to build retaining sea walls (Moreau 2004, 2005, 2007), such as the construction of a 141-m sea wall in the Martinez Marina in Canada or the construction of 
a 421-m long-shore protective breakwater in Keyport, New Jersey, USA. However, there are no examples of composites being used to build caissons for seaports.

\section{BACKGROUND}

\section{Background of the project}

During the last two decades, Fuerteventura (one of the Canary Islands in Spain) has developed extensively, and sea transported bulk freight has increased by more than $80 \%$ (Consejo de Usuarios del transporte Marítimo y Aéreo de Las Palmas [CUTMAP], 2005). These developments, coupled with the demographic predictions, have prompted decision to build new seaport infrastructures that will meet future social objectives. Puerto del Rosario, Fuerteventura's most important seaport, has a 305 m long ocean cruiser pier. Consequently, an 84-m extension is needed to create better mooring conditions for the $280 \mathrm{~m}$ long ocean-going cruise ships.

In 2012, Las Palmas Port Authority, which controls Puerto del Rosario, decided to build two square $12 \times 12 \mathrm{~m}$ wide mooring dolphins, separated by $30 \mathrm{~m}$, using concrete blocks (see Figure 1). As there were no-floating caisson manufacturing ships in Puerto del Rosario or in the surrounding seaports, this was an exceptional opportunity to design and test a new glass/epoxy (GFRP) caisson construction technique using pre-fabricated elements that would be transported to Puerto el Rosario for assembly on site. Lightweight GFRP caissons allow light cranes to be used to assemble all of the elements and launch the final caisson. 


\section{Description of the technique}

To take advantage of GFRP's outstanding tensile properties, the mooring dolphins were designed as cylinders. As circumferential stresses were the most important forces in the design - soil pressure inside of the caisson is double the external water pressure, most of the cylindrical structure was tensile stressed. Consequently, a $12 \mathrm{~m}$ diameter, $13.3 \mathrm{~m}$ high cylindrical GFRP caisson was designed and filled with soil to prevent sliding or turning (see Figure 2-a-b). At the top of the GFRP cylinder, a 2-m reinforced concrete slab that rests over the GFRP walls was added to fix a bollard for the installation of the mooring points. Moreover, this concrete slab was used to distribute loads into the GFRP cylinder in the event of ships colliding with the mooring dolphins. The concrete slab was not considered to be supported by the soil filling the GFRP cylinder, but rather, it was considered to be supported by GFRP caisson walls. As the concrete slab's own weight is an important compression load on the GFRP cylinder, a second cylinder was placed inside, separated by $0.5 \mathrm{~m}$, with 24 vertical stiffeners to prevent buckling. At the bottom of the GFRP cylinder, there was a composite sandwich panel slab foundation with vertical and radial stiffeners. When the GFRP cylinder was finally installed, a 0.5-m concrete slab was also poured into the bottom. This slab was placed once the composite structure was launched into the sea. The composite structure's design weight for this first GFRP caisson was $21,000 \mathrm{~kg}$. This is important as it enables the caisson structure to be launched with a light crane, which in turn enables the pre-fabricated elements to be used in the caisson. In comparison, this option is 50 times lighter than the traditional concrete alternative, which could not be pre-fabricated in a similar manner. All designs and calculations have been performed according to established design standards. For the specific case of Puerto del Rosario's new 
mooring dolphins, the design fulfilled all required margins of safety, according to Recommendations for Maritime Works (Spanish Standards, 2011), the Spanish Concrete Design Code (Spanish Standards, 2008), and the Eurocomp Design Code (Clarke, 1996).

\section{DESIGN AND ANALYSIS OF THE STRUCTURE}

\section{Material selection}

The durability and corrosion resistance of composites is well known, and there are extensive references that address this, but unfortunately, there are few examples of real civil marine structures in the world. The main reason why GFRP is not used in maritime civil constructions is because the seawater environment effects degrade the long-term mechanical properties of GFRP composites and the interlaminar shear strength (ILSS) (Nguyen et al., 1997). The effects of seawater vary, however, depending on the type of resin used, as there are several types that can be used for maritime structures such as phenols, polyurethane, polyester, vinylester and epoxy. As polyester, vinylester and epoxy resins are the most commonly used (Kootsookos \& Mouritz, 2004), they have been well covered in several scientific journal publications on different aspects of seawater effects. From among the various publications, different conclusions have been presented (Liao et al., 1999).

After having analyzed scientific publications related to the degradation of mechanical properties in phenols, polyurethane, polyester, vinylester (Gellert \& Turley, 1999) and epoxy GFRP composites, the conclusion is that the most suitable resin for this specific application is 
epoxy because, after moisture stabilization has occurred, the degradation of the mechanical properties decreases and stabilizes. The tensile strength of a glass/epoxy resin composite decreases $24 \%$ after 90 days, and the flexural strength reduces by $35 \%$ (Weib et al., 2011). After an additional 60 days, this value stabilizes, thus indicating that epoxy resin could be safely used for structural design, applying a conservative mechanical strength margin of safety of 2; this means that the material strength is reduced by $50 \%$ (Garcia-Espinel et al., 2015b). Another factor considered in the design was that the cyclic occurrence of UV effects combined with a seawater environment influence the degradation of the mechanical properties (Kumaret al., 2002). Several authors have studied the effects of UV radiation and moisture on glass fiber composites and concluded that the changes in mechanical properties due to UV radiation have a limited influence, affecting, above all, the material's surface (Correia et al, 2005). Chromatic and gloss changes due to UV radiation have been resolved by applying a UV-resistant coating on the top $4 \mathrm{~m}$ of the composite structure. As this is the area most affected by UV radiation, it is deemed the area that needs protection. The biodegradation of composites was analyzed to improve the design, and the conclusion was that epoxy and vinylester resins, carbon fibers, and epoxy composites are not adversely affected by microbial species (Wagner et al., 1996). Moreover, fatigue analysis conclusions indicate that as expected, the excellent fatigue performance of epoxy glass fiber composites does not change in seawater environments (Shan \& Liao, 2002; Boothby \& Johnstone, 1997; Poodts et al., 2013). Finally, the material selected for this solution was a glass/epoxy composite (GFRP), and an aluminum honeycomb was used to increase the composite stiffness in vertical walls and in the bottom slab. The glass fibers used 
were UD1200HM and B45800G, and the aluminum honeycomb used was ALUNID 3000- $\varnothing 1 / 4-$ 80-L1250-W2500-P-T50 (see Table 1).

\section{Load analysis}

A load analysis was conducted to determine the worst-case affecting the caisson structure construction process and its final use. The following load scenarios were considered for load analysis:

- GFRP caisson lifting process

- Flotation

- Anchoring

- Final installation

The following main loads affected the GFRP caisson:

- GFRP caisson and concrete superstructure weight

- Filling material weight and lateral pressure

- External hydrostatic pressure

- Mooring load $(1,500 \mathrm{kN})$

- Ship impact load (918 kN)

- Pressure of wave crest

- Pressure of sine wave 
- Seismic loads

Four different wave heights were considered under various work conditions (Spanish Standards 2011, p. 27):

- Usual operational conditions: CT1

- Extreme working conditions (wave return period $\mathrm{Tr}=50$ years): $\mathrm{CT} 2$

- Exceptional working conditions (wave return period $\operatorname{Tr}=500$ years): CT3.1

- Wave conditions under seismic loads: СT3.32

Therefore, the wave conditions considered are presented in Table 2:

All considered loads are combined with wave conditions in different load scenarios (see Table 3).

The GFRP caisson is installed on top of a 3.4-m rock bed of 500 to $1,000 \mathrm{kN}$ of rocks. Thus, the drained deformation modulus considered was $7 \mathrm{MPa}$, and the ballast modulus was $916 \mathrm{kN} / \mathrm{m} 3$.

\section{Calculation criteria}

The composite structure was designed using a commercial finite element model (FEM) software used to design complex structures. To verify the composite integrity calculations, the criterion used was Tsai-Hill (Jones, 1999) (see eq.1): 
$I_{F}=\frac{\sigma^{2} 11}{X^{2}}+\frac{\sigma^{2} 22}{Y^{2}}-\frac{\sigma_{11} \sigma_{22}}{X^{2}}+\frac{\sigma^{2} 12}{S^{2}}<1.0 \quad$ (eq. 1$)$

where

- $\quad I_{F}=$ Tsai Hill index

- $\mathrm{X}=x_{t}$ if $\sigma_{11} \geq 0$ and $\mathrm{X}=x_{c}$ if $\sigma_{11}<0$

- $\mathrm{Y}=y_{t}$ if $\sigma_{22} \geq 0$ and $\mathrm{Y}=y_{c}$ if $\sigma_{22}<0$

- $x_{t}, y_{t}$ are ultimate tensile strengths in $\mathrm{X}, \mathrm{Y}$ direction

- $x_{c}, y_{c}$ are ultimate compressive strengths in $\mathrm{X}, \mathrm{Y}$ direction

- $\mathrm{S}$ is ultimate in-plane shear strength

- $\sigma_{i i}=$ stress in ii axes

The calculation criteria considered is that if the Tsai-Hill index value is higher than 1 , the composite structure begins to fail. In this project, as there was uncertainty about the loss in strength due to composite durability in seawater, all mechanical strength properties of composites were decreased by $50 \%$ to guarantee safety.

The skin's shear stress margin of safety $\left(M S_{\text {skin }}>1\right)$ was verified using interlaminar shear strength criteria (see eq. 2):

$M S_{\text {Skin }}=\frac{\sqrt{\sigma_{31}^{2}+\sigma_{23}^{2}}}{\sigma_{I L S S}^{u}}-1$ 
where:

- $M S_{\text {skin }}=$ skin's shear stress margin of safety

- $\sigma_{I L S S}^{u}=$ maximum interlaminar shear strength

- $\sigma_{i i}=$ stress in ii axes

Core strength was verified $\left(M S_{\text {core }}<1\right)$ using (see eqs. 3, 4 and 5):

$\tau_{13}=\frac{Q_{1}}{c} \quad$ (eq. 3)

$\tau_{23}=\frac{Q_{2}}{c} \quad$ (eq. 4$)$

$M S_{\text {core }}=\frac{S_{s l} S_{s w}}{\sqrt{S_{s w}^{2} \tau_{13}^{2}+S_{s l}^{2} \tau_{23}^{2}}}-1$

where:

- $M S_{\text {core }}=$ core shear stress margin of safety

- $\tau_{i i}=$ shear stress following $\mathrm{i}$ axes

- $c=$ core thickness

- $S_{s i}=$ ultimate shear stress in i axes (w: width and I: longitudinal)

- $Q_{i}=$ shear load following i axe 
Moreover, buckling and local instability sandwich failure modes, such as face wrinkling, intracell buckling or dimpling, and local compression or crimping, were verified using the analysis of sandwich structures design criteria (America Society for Metals [ASM], 2001).

\section{Finite element model design}

The numerical model was established using laminate FEM elastic and orthotropic elements to simulate the composite material and the honeycomb. Solid elements were used to simulate concrete, while filling material was not simulated but rather considered as a load. The model had more than 28,000 nodes and consisted of 25,000 laminate parts and 3,000 solid elements. As a buckling analysis was performed on this structure, the GFRP caisson was studied in the final scenario where the mooring load needed to start buckling was calculated. The first buckling mode occurred at an eigenvalue of 4.1. As shown in the buckling chart, the GFRP caisson is far from buckling (see Figure $4 \mathrm{a}-\mathrm{b}$ ).

Analyses of the loads considered in different scenarios and the stress results of the GRFP caisson show that the most restrictive scenarios were CT2-b and CT1-d (see Table 3). Hence, the composite laminate configuration was designed for these scenarios in each part of the GRFP caisson. As evidenced in the stress analysis results, the GFRP caisson structure has a Tsai-Hill index lower than 1 , as maximum values are found at the bottom of the caisson but never exceed 1. Furthermore, the structure's bottom slab and vertical and base stiffeners were analyzed, but all of them exhibited low Tsai-Hill index levels (see Table 4 and Figures 5 a-b-c-d). Shear stress was also analyzed, but all results from the various scenarios were well below the 
maximum value of $30 \mathrm{MPa}$. The honeycomb core was checked, and shear stresses were less than 1.5 MPa and 2.1 MPa in different directions (see Figure $6 \mathrm{a}-\mathrm{b}$ ). All shear stresses scenarios provided MS values higher than 1 (see eq. 5). The composite sandwich buckling and local instability failure modes were also verified, and MS was always found to be higher than 1 .

The laminate configuration was examined in three different areas - area A, at the bottom, which was $6 \mathrm{~m}$ high; area $\mathrm{B}$, in the middle, which was from $6 \mathrm{~m}$ to $9.4 \mathrm{~m}$ high; and area $\mathrm{C}$, the rest of the GFRP caisson. The configuration was verified using the FEM, and angle measures from the vertical cylindrical alignment were as follows:

- External skin (B45800G):

- $\mathrm{A}: 0 / 0 / 45 / 0 / \mathrm{H} 90 / 0 / 45 / 0 / 0$

- B: $0 / 45 / 0 / H C 90 / 0 / 45 / 0$

- C: $0 / 0 / \mathrm{HC} 9 / 0 / 0$

- Internal skin (B45800G):

- $\mathrm{A}: \mathrm{0} / 0 / 45 / 0 / \mathrm{HC} 9 \mathrm{O} / 0 / 45 / 0 / 0$

- B: $0 / 0 / 45 / H C 90 / 45 / 0 / 0$

- Stiffeners (B45800G):

- $45 / 0 / 0 / 45 / 0 / 0 / 45 / 45 / 0 / 0 / 45 / 0 / 0$

- Basement (UD1200HM):

- $45 / 0 / 0 / 45 / 0 / 0 / 45 / 45 / 0 / 0 / 45 / 0 / 0$

The final configuration of the GFRP caissons found that their total weight using composite materials was $20,000 \mathrm{~kg}$. This allows for GFRP caissons to be pre-fabricated in a factory in the 
south of Spain, shipped to Fuerteventura, assembled on the Puerto del Rosario dock and launched with a light crane. In contrast, the concrete block option weighs 3,600,000 kg (180 times more) and thus requires a large surface for the installation of a concrete block manufacturing factory $\left(6,000 \mathrm{~m}^{2}\right)$, an alternative that would affect the port's functionality. The GFRP caisson is also a sustainable solution for building ports because the installation process reduces $\mathrm{CO}_{2}$ emissions by $75 \%$ compared to the concrete option.

\section{CONSTRUCTION}

\section{Manufacture, transport and assembling of GFRP caissons}

GFRP composite caissons were manufactured using a resin infusion technique in a factory located in Jerez, a region in the south of Spain. First, the composite bases for the caissons were manufactured, and all parts were prepared. The caisson base was constructed of 12 symmetrical elements, all of which were radial parts of the circular structure, which had an external radius of $6 \mathrm{~m}$. These foundation elements were designed to be moved by hand, not by cranes, at the work site. The caisson walls were also manufactured in 12 elements. Each wall element was made of two pieces, the outer skin, with a radius of $6 \mathrm{~m}$, and the inner skin, with a radius of $5.4 \mathrm{~m}$, and were composed of composite sandwich panels. They were then bonded together and pre-assembled at the factory. The assembly of the caisson walls was accomplished using specially manufactured mechanical elements that overlapped both caisson walls and were then pinned to the walls. 
The GFRP caisson elements were transported by truck from the factory in Jerez to Huelva Harbor. In Huelva, a ship transported the elements by sea to Fuerteventura, where they were unloaded in the Puerto del Rosario Harbor. The elements were bonded together using a highstrength adhesive, and all caisson base elements were moved and assembled on-site by hand. A light crane was used exclusively to move groups of elements and to support the assembly process. The caisson walls were installed to form the GFRP caisson using a 30 tons crane and were then stabilized by fixing the caisson walls to the ground with struts (see Figure $6 a-b)$. Special elements for fixing two caisson wall elements were installed using bolts as mechanical fixations. Once the caisson was completely assembled, a crane launched it into the water (see Figure 7-a-b). In the case of Puerto del Rosario's new mooring dolphins, their final weight was 55 tons including the GFRP caisson, the special plates to join wall elements, the mechanical fixation elements and the steel bar reinforcement for the inner concrete bottom slab. A 0.5-m thick concrete slab was constructed at the bottom of the cylinder after the launching operation. The caisson was then towed to its final position, where a simple water ballasting operation was conducted to bottom-found the structure. Once placed in its final position, the caisson was filled with a granular material.

The work was completed with the installation of bollards and fenders on a concrete superstructure built on the top. The 2-m thick superstructure had a circular cross-section with the bottom embedded in the caisson, and two walkways provided personnel access to the mooring dolphins for maintenance operations (Garcia-Espinel et al., 2015a). 


\section{CONCLUSIONS}

Summing up, in comparison with traditional concrete techniques to enlarge sea ports, GFRP caissons construction technology presents several benefits:

- $\quad$ Low weight of GFRP caissons and easy transport of the pieces worldwide.

- Using GFRP, big cranes or complex equipment are not necessary for placing caissons in the water due to their reduced weight.

- Fabrication in factory and assembly on site reduces the need for big construction areas.

- Port operations are not affected by the construction work.

- The construction process reduces emissions. In this case a reduction in the $\mathrm{CO}_{2}$ emission of up to 4 times less than a conventional solution was calculated.

- The use of composite materials minimizes the use of aggregate and so the necessity of quarrying works for extracting it.

- Waste generation is reduced because GFRP caissons are produced in a factory and not in the site work.

- The sea bottom surface occupied is reduced because of the circular shape of the caisson bottom, reducing impact on the marine ecosystem. Reduction of occupied area is estimated at $20 \%$.

- Reduced maintenance operations due to the use of GFRP.

The construction of GFRP caissons can be improved with the following suggestions: 
- Bonding between composite elements should be avoided with hot temperatures. In this case in Fuerteventura, adhesives were applied in summer with lots of problems due to high temperatures. Also adhesive bonding materials must be improved in order to reduce hand labor time and reach higher strength.

- Laboratory tests must be performed prior to any changes in the resin used or the manufacturing process followed. Degradation of the mechanical properties of composites depends on both factors. Thus, a complete scientific study must be started in order to find the material margin of safety to predict degradation of mechanical properties without doing laboratory tests.

- Civil engineering standards must be improved in order to let designers use composite materials. In Puerto del Rosario project all calculations and designs were referred to aeronautical standards and codes. Specific standards for using FRP composite materials must be developed for civil engineering applications.

\section{REFERENCES}

American Society for Metals 2001. ASM Handbook Composites Volume 21, ASM. Material Park, Ohio.

Ashpiz,E.S., Egorov, A.O. \& Ushakov, A.E., 2010. 'Application of composite materials for the protection of sea shores and engineering structures', in: Favro, S. and Brebbia, C.A. (Eds). Island Sustainability. WIT Press, Wessex, pp.231-238. 
Benmokrane, B., Chaallal, O. \& Masmoudi, R. 1995. 'Glass fibre reinforced plastic (GFRP) rebars for concrete structures'. Construction and Building Materials. 9 (6), 353-364.

Boothby, P.J. \& Johnstone, C.D. 1997. 'Fibre-reinforced caissons for offshore applications'. Composite Structures. 38 (1-4), 141-149.

Clarke, J.L. 1996. Structural Design of Polymer Composites: Eurocomp Design Code and Background Document, Taylor \& Francis, London, UK.

Consejo de Usuarios del transporte Marítimo y Aéreo de Las Palmas 2005. El transporte Marítimo de Mercancías en Canarias. Una visión actual de los usuarios. Viewed 20 February 2015. (Spanish) http://www.datosdelanzarote.com/uploads/doc/20060301211235714informe_2005040 8.pdf

Correia, J.R., Cabral-Fonseca S., Branco F.A., Ferreira J.G., Eusébio M.I. \& Rodrigues M.P. 2005. 'Durability of Glass Fibre Reinforced polyester (GFRP) pultruded profiles used in civil engineering applications'. Departamento de Engenharia Civil, Arquitectura e Georrecursos (eds), Composites in Construction - Third International Conference. Lyon, France. Viewed 21 of February 2015. http://www.civil.ist.utl.pt/ jcorreia/Papers/ICPaper6.pdf

Creative Pultrusion 2011. San Francisco West Harbor Renovation Project. San Francisco CA. December 2011 (Phase 1), viewed 28 November 2014. http://www.creativepultrusions.com/pultruded-systems/pipe-piling/san-francisco-westharbor-renovation-project/ 
Creese R.C., Gangarao H. 2004. Polymer composites III. Transportation infrastructure, defense and novel applications of composites. Destech publications, Pennsylvania, PA.

Delf Infra Composites 2014. Bridges and bridge decks with composites. Nijmegen, The Netherlands, viewed 21 February 2015. http://www.infracomposites.com/bridges-andbridge-decks-with-composites.html

Franco, L., 1994. 'Vertical breakwaters: the Italian experience'. Coastal Engineering. 22 (1-2), 31-55.

Frihy, O.E., 2001. 'The necessity of environmental impact assessment (EIA) in implementing coastal projects: lessons learned from the Egyptian Mediterranean Coast'. Ocean \& Coastal Management. 44 (7-8), 489-516

Garcia-Espinel, J.D., Alvarez-Garcia-Lubén, R., Gonzalez-Herrero, J.M. \& Castro-Fresno, D., 2015a. 'Glass fiber-reinforced polymer caissons used for construction of mooring dolphins in Puerto del Rosario harbor (Fuerteventura, Canary Islands)'. Coastal Engineering. 98. 16-25

García-Espinel, J.D., Ayala-Luna, J. \& Clemente-Ortega, L.R. 2012. 'Ejemplo del uso de materiales innovadores en la ingeniería civil. Pasarela peatonal en Cuenca'. Congreso Nacional de Ingeniería Civil, Valencia. (Spanish)

Garcia-Espinel, J.D.; Castro-Fresno, D.; Parbole Gayo, P. \& Ballester-Muñoz F. 2015b. 'Effects of sea water environment on glass fiber reinforced plastic materials used for marine civil engineering constructions'. Material and Design. 66. 46-50

García-Espinel, J.D. \& Del Amo-Sanz, E. 2010. 'Duplicación de la M-IIl y variante de Fuente el Saz de Jarama'. Cauce 2000. 32-39. (Spanish) 
Gellert, E.P. \& Turley, D.M., 1999. 'Seawater immersion ageing of glass-fibre reinforced polymer laminates for marine applications'. Composites Part A: Applied Science and Manufacturing, 30 (11), 1259-1265.

Hoshikuma, J., Kawashima, K., Nagaya, K., \& Taylor, A., 1997. 'Stress-Strain model for confined reinforced concrete in bridge piers'. J. Structural Engineering.123 (5), 624-633.

Jones, R.M. 1999. Mechanics of composite materials, Taylor \& Francis, Philadelphia, PA.

Kootsookos A., Mouritz A.P., 2004. 'Seawater durability of glass- and carbon-polymer composites'. Composites Science and Technology. 64 (10-11), 1503-1511

Kumar,B.G., Singh, R.P. \& Nakamura, T., 2002. 'Degradation of Carbon Fiber-reinforced Epoxy Composites by Ultraviolet Radiation and Condensation'. Journal of Composite Materials. 36 (24), 2713-2733.

Liao K., Schultheisz C.R., Hunston D.L., 1999. 'Effects of environmental aging on the properties of pultruded GFRP Composites'. Composites Part B: Engineering. 30 (5), 485-493.

Mieres, J.M., Calvo,I., Miravete, A., Gutiérrez, E., Shahidi, E., López, C., J. Cuartero, J., Comino, P., \& Guzmán de Villoria, R., 2006. 'Description of a traffic bridge of the Cantabrian Speedway made of composite materials'. Materiales de Construcción. 56 (284), 81-86.

Moreau, Jeff. 2004. Carbon fiber re-enforced composite sheet piling segments. US Patent number 0126193. Sol. 10/702,351.

Moreau, Jeff. Multipanel seawall segment. 2005. US Patent number 0058514 A1. Sol. 10/939,708.

Moreau; Jeff. 2007. Re-enforced composite sheet piling segments. US Patent number 7182551. Sol. 10/286,564. 
Nguyen,T., Aouadi, K., Alsheh, D. \& Chin,J. 1997. 'Effects of Civil Engineering Environments of Interfacial Properties of Polymer/Glass Fiber Composites', in Hui, D., (ed). Composites Engineering, 4th International Conference. International Community for Composites Engineering (ICCE/4). University of New, Hawaii, pp 725-726.

Poodts, E., Minak, G. \& Zucchelli, A., 2013. 'Impact of sea-water on the quasi static and fatigue flexural properties of GFRP'. Composite Structures. 97, 222-230.

Potyrała P.B., 2011. Use of Fibre Reinforced Polymer Composites in Bridge Construction. State of the Art in Hybrid and All-Composite Structures. Universidad Politécnica de Cataluña. Barcelona. BA.

Puertos del Estado 2008. Guía de buenas prácticas para la ejecución de obras marítimas, PE, Madrid. (Spanish)

Shan, Y. \& Liao, K. 2002. 'Environmental fatigue behavior and life prediction of unidirectional glass-carbon/epoxy hybrid composites'. International Journal of Fatigue. 24 (8), 847859.

Spanish Standards, 2008. EHE-08. Instrucción del hormigón estructural. Ministerio de Fomento. Gobierno de España. (Spanish)

Spanish Standards 2011. ROM 2.0-11 Recomendaciones para el proyecto y ejecución en las Obras de Atraque y Amarre. Ministerio de Fomento. Gobierno de España. (Spanish)

Strongwell 2009. Leri footbridge buil with strongwell's lightweight, corrosion resistans FRP. Strongwell, viewed 21 February 2015. http://www.strongwell.com/news/lerifootbridgebuilt-with-strongwells-lightweight-corrosion-resistant-frp/ 
Wagner,P.A., Little,B.J., Hart. K.R. \& Ray, R.I., 1996. 'Biodegradation of Composite Materials'. International Biodeterioration \& Biodegradation. 38 (2), 125-132.

Wei,B., Cao,H., Song,S. 2011. 'Degradation of basalt fibre and glass fibre/epoxy resin composites in seawater'. Corrosion Science. 53 (1), 426-431.

\section{Figure Captions}

Figure 1 - General view of the construction of two mooring dolphins in Puerto del Rosario (Fuerteventura, Spain) (image by José Daniel García Espinel)

Figure 2 - GFRP caisson structure for mooring dolphins in Puerto del Rosario (Fuerteventura, Spain) (a) top view; (b) general view; (c) cross section

Figure 3 - Details of wave conditions used in the GFRP design; (a) pressure of wave crest; (b) pressure of wave sine

Figure 4.- Details of the FEM model and first buckling mode for mooring load ( $\lambda=4.1$ ); (a) FEM elements model; (b) first buckling mode for mooring load (Eigenvalue=4.1)

Figure 5 Tsai-Hill failure index for the (a) external side; (b) internal side, (c) vertical wall stiffeners, and (d) base stiffeners 
Figure 6 Shear stresses $(\mathrm{Pa})$ in skin and honeycomb sandwich structure on the external side.

Figure 7 - Assembly of GFRP caisson in Puerto del Rosario Harbor; (a) shear stress in skin, outer wall (Pa); (b) shear stress in honeycomb sandwich core, outer wall (Pa). (images by José Daniel García Espinel)

Figure 8 (a) Launching and (b) towing of the GFRP caisson in Puerto del Rosario Harbor to its final installation place (images by José Daniel García Espinel)

Figure 9 (a) An installed GFRP caisson and (b) a first cruiser docked in new mooring dolphins (images by José Daniel García Espinel)

Table 1 - Mechanical properties of GFRP composites and ALUNID honeycomb used in the caisson design

\begin{tabular}{|c|c|c|c|c|}
\hline Mechanical Properties & Nomenclature & $\begin{array}{c}\text { GFRP } \\
\text { COMPOSITE } \\
\text { B45800G } \\
\end{array}$ & $\begin{array}{c}\text { GFRP } \\
\text { COMPOSITE } \\
\text { UD1200HM }\end{array}$ & $\begin{array}{c}\text { HONEYCOMB } \\
\text { ALUNID } \\
\text { HC90 } \\
\end{array}$ \\
\hline Composite thickness & $\mathrm{t}(\mathrm{mm})$ & 0.72 & 0.69 & N.A. \\
\hline Honeycomb thickness & $\mathrm{c}(\mathrm{mm})$ & N.A. & N.A. & 50 \\
\hline Fiber volume fraction & $\mathrm{Vf}(\%)$ & $71.7 \%$ & $71.1 \%$ & N.A. \\
\hline Density & $\rho\left[\mathrm{kg} / \mathrm{m}^{3}\right]$ & 1,905 & 1,905 & 83 \\
\hline Ultimate tensile strength 0 o & $\mathrm{x}_{\mathrm{t}}[\mathrm{MPa}]$ & 114 & 871 & N.A. \\
\hline Ultimate tensile strength 900 & $\mathrm{y}_{\mathrm{t}}[\mathrm{MPa}]$ & 114 & 37 & N.A. \\
\hline $\begin{array}{l}\text { Ultimate Compression } \\
\text { strength } 0 \text { o }\end{array}$ & $\mathrm{x}_{\mathrm{c}}[\mathrm{MPa}]$ & 116 & 610 & N.A. \\
\hline $\begin{array}{l}\text { Ultimate Compression } \\
\text { strength } 90 \text { o }\end{array}$ & $\mathrm{y}_{\mathrm{c}}[\mathrm{MPa}]$ & 116 & 37 & N.A. \\
\hline Ultimate In-plane shear & $\mathrm{S}[\mathrm{MPa}]$ & 304 & 43 & N.A. \\
\hline
\end{tabular}




\begin{tabular}{|l|l|r|r|r|} 
strength & & & \\
\hline $\begin{array}{l}\text { Ultimate shear strength width } \\
\text { axis }\end{array}$ & $\mathrm{S}_{\mathrm{sw}}[\mathrm{MPa}]$ & $\mathrm{N} . \mathrm{A}$. & N.A. & 2.1 \\
\hline $\begin{array}{l}\text { Ultimate shear strength } \\
\text { longitudinal axis }\end{array}$ & $\mathrm{S}_{\mathrm{sl}}[\mathrm{MPa}]$ & $\mathrm{N} . \mathrm{A}$. & N.A. & 1.5 \\
\hline Young's modulus 0 & $\mathrm{E}_{\mathrm{x}}[\mathrm{GPa}]$ & 11.5 & 40.7 & 0.5 \\
\hline Young's modulus 90 & $\mathrm{E}_{\mathrm{y}}[\mathrm{GPa}]$ & 12.4 & 10.6 & 0.5 \\
\hline Shear Modulus axis 12 & $\mathrm{G}_{12}[\mathrm{MPa}]$ & 13.8 & 3.3 & 0.1 \\
\hline Shear Modulus axis 13 & $\mathrm{G}_{13}[\mathrm{MPa}]$ & 13.8 & 3.3 & 440.0 \\
\hline Shear Modulus axis 23 & $\mathrm{G}_{23}[\mathrm{MPa}]$ & 13.8 & 3.3 & 220.0 \\
\hline Poisson's Ratio & $\mathrm{V}[-]$ & 0.5 & 0.3 & 0.0 \\
\hline $\begin{array}{l}\text { Maximum interlaminar shear } \\
\text { strength }\end{array}$ & $\sigma_{\mathrm{ILSS}}^{\mathrm{u}}[\mathrm{MPa}]$ & 30 & 45 & N.A. \\
\hline
\end{tabular}

Table 2.- Wave conditions used in GFRP design

\begin{tabular}{|c|c|c|c|c|c|c|c|c|}
\hline \multirow[b]{2}{*}{ Scenario } & \multirow[b]{2}{*}{$\begin{array}{c}\text { Wave } \\
\text { height } \\
\text { Hs } \\
\text { (m) }\end{array}$} & \multirow[b]{2}{*}{$\begin{array}{c}\text { Return } \\
\text { Period } \\
\quad \mathbf{T} \\
\text { (years) }\end{array}$} & \multicolumn{3}{|c|}{ Wave crest } & \multicolumn{3}{|c|}{ Wave sine } \\
\hline & & & $\begin{array}{c}\text { Water } \\
\text { pressure } \\
\text { p1 (kPa) }\end{array}$ & $\begin{array}{c}\text { Water } \\
\text { pressure } \\
\text { p2 (kPa) }\end{array}$ & $\begin{array}{l}\text { Water } \\
\text { pressure } \\
\text { height } \\
\text { d (m) }\end{array}$ & $\begin{array}{c}\text { Water } \\
\text { pressure } \\
\text { p4 (kPa) }\end{array}$ & $\begin{array}{c}\text { Water } \\
\text { pressure } \\
\text { p2 }(\mathrm{kPa})\end{array}$ & $\begin{array}{c}\text { Water } \\
\text { pressure } \\
\text { height } \\
\text { d (m) }\end{array}$ \\
\hline СТ1 & 0.7 & 500 & 8.4 & 4.6 & 1.9 & 12.1 & 7.0 & 1.2 \\
\hline СТ2 & 2.3 & 50 & 27.4 & 13.4 & 6.3 & 22.2 & 20.2 & 3.2 \\
\hline CT3.1 & 3.0 & 500 & 36.2 & 19.4 & 8.1 & 40.1 & 28.1 & 4.0 \\
\hline CT3.32 & 0.5 & 50 & 5.6 & 2.8 & 1.3 & 8.4 & 4.4 & 0.8 \\
\hline
\end{tabular}

Table 3 - Combination coefficients used to calculate the load hypothesis considered in the GFRP design

\begin{tabular}{|l|r|r|r|r|r|r|r|r|}
\hline Scenario & $\begin{array}{c}\text { Own } \\
\text { weight }\end{array}$ & Filling & $\begin{array}{c}\text { Hydro } \\
\text { load }\end{array}$ & $\begin{array}{r}\text { Mooring } \\
\text { load }\end{array}$ & $\begin{array}{c}\text { Ship } \\
\text { impact } \\
\text { load }\end{array}$ & Crest & Sine & $\begin{array}{c}\text { Seismic } \\
\text { Load }\end{array}$ \\
\hline CT1-a & 1.4 & 1.4 & 1.4 & 0.0 & 0.0 & 1.5 & 0.0 & 0.0 \\
\hline CT1-b & 1.4 & 1.4 & 1.4 & 0.0 & 1.5 & 1.5 & 0.0 & 0.0 \\
\hline CT1-c & 1.4 & 1.4 & 1.4 & 0.0 & 0.0 & 0.0 & 1.5 & 0.0 \\
\hline CT1-d & 1.4 & 1.4 & 1.4 & 1.5 & 0.0 & 0.0 & 1.5 & 0.0 \\
\hline CT1-e & 1.4 & 1.4 & 1.4 & 1.5 & 0.0 & 1.5 & 0.0 & 0.0 \\
\hline CT1-f & 1.4 & 1.4 & 1.4 & 0.0 & 1.5 & 0.0 & 1.5 & 0.0 \\
\hline CT1-g & 1.4 & 1.4 & 1.4 & 1.5 & 0.0 & 0.0 & 0.0 & 0.0 \\
\hline CT1-h & 1.4 & 1.4 & 1.4 & 0.0 & 1.5 & 0.0 & 0.0 & 0.0 \\
\hline CT2-a & 1.4 & 1.4 & 1.4 & 0.0 & 0.0 & 1.5 & 0.0 & 0.0 \\
\hline
\end{tabular}




\begin{tabular}{|l|r|r|r|r|r|r|r|r|}
\hline CT2-b & 1.4 & 1.4 & 1.4 & 0.0 & 0.0 & 0.0 & 1.5 & 0.0 \\
\hline CT3.1-a & 1.0 & 1.0 & 1.0 & 0.0 & 0.0 & 1.5 & 0.0 & 0.0 \\
\hline CT3.1-b & 1.0 & 1.0 & 1.0 & 0.0 & 0.0 & 0.0 & 1.5 & 0.0 \\
\hline CT3.32-a & 1.0 & 1.0 & 1.0 & 0.0 & 0.0 & 0.0 & 0.0 & 1.0 \\
\hline CT3.32-b & 1.0 & 1.0 & 1.0 & 0.6 & 0.0 & 0.0 & 0.0 & 1.0 \\
\hline CT3.32-c & 1.0 & 1.0 & 1.0 & 0.6 & 0.0 & 1.0 & 0.0 & 1.0 \\
\hline CT3.32-d & 1.0 & 1.0 & 1.0 & 0.6 & 0.0 & 0.0 & 1.0 & 1.0 \\
\hline Buckling & 1.0 & 1.0 & 1.0 & $\lambda$ & 0.0 & 0.0 & 0.0 & 0.0 \\
\hline
\end{tabular}

Note: The letter at the end of the scenario is used to represent different load and work condition combinations (Spanish Standards 2011)

Table 4 - GFRP caisson external and internal skins and stiffeners, stresses and moments, worsecase scenarios and Tsai Hill index.

\begin{tabular}{|c|c|c|c|c|c|c|c|c|}
\hline Height & Scenarios & $\begin{array}{c}\text { Tsai- } \\
\text { H } \\
\text { index }\end{array}$ & $\begin{array}{c}\mathrm{SF} 1 \\
(\mathrm{kN} / \mathrm{m})\end{array}$ & $\begin{array}{c}\text { SF2 } \\
(\mathrm{kN} / \mathrm{m})\end{array}$ & $\begin{array}{c}\text { SF3 } \\
(\mathrm{kN} / \mathrm{m})\end{array}$ & $\begin{array}{c}\mathrm{SM} 1 \\
(\mathrm{kNm} / \mathrm{m})\end{array}$ & $\begin{array}{c}\mathrm{SM} 2 \\
(\mathrm{kNm} / \mathrm{m})\end{array}$ & $\begin{array}{c}\mathrm{SM} 3 \\
(\mathrm{kNm} / \mathrm{m})\end{array}$ \\
\hline \multicolumn{9}{|c|}{ GFRP caisson external skin } \\
\hline 2 & CT2-b & 0.75 & 244 & -28 & -143 & -0.4 & -13.7 & 4.6 \\
\hline 5 & CT2-b & 0.65 & 284 & -33 & -103 & 1.6 & -0.8 & 3 \\
\hline 7.5 & CT2-b & 0.75 & 303 & -30 & -43 & 0.3 & -12.6 & 1.2 \\
\hline 10 & CT1-d & 0.68 & 113 & -54 & -49 & 1.7 & -0.5 & 1.2 \\
\hline 12 & CT1-d & 0.66 & 21 & -141 & -47 & 3.6 & -1.1 & 1.4 \\
\hline \multicolumn{9}{|c|}{ GFRP caisson internal skin } \\
\hline 2 & CT2-b & 0.8 & 166 & -145 & -237 & -3.5 & 8.8 & -6.2 \\
\hline 5 & CT2-b & 0.6 & 265 & -107 & -138 & -2.3 & 15.9 & -3.8 \\
\hline 7.5 & CT2-b & 0.7 & 185 & -107 & -60 & -1.9 & 10.8 & -1.6 \\
\hline 10 & CT2-b & 0.5 & 131 & -103 & -52 & -2 & 7.1 & -1.2 \\
\hline
\end{tabular}




\begin{tabular}{|c|c|c|c|c|c|c|c|c|}
\hline 12 & CT1-d & 0.5 & 3 & -34 & -107 & -1 & 0.4 & -2.7 \\
\hline \multicolumn{7}{|c|}{ GFRP caisson stiffeners } \\
\hline 2 & CT2-b & 0.4 & -213 & 56 & -254 & N.A. & N.A. & N.A. \\
\hline 5 & CT1-d & 0.2 & -298 & 42 & 9 & N.A. & N.A. & N.A. \\
\hline 7.5 & CT1-d & 0.3 & -326 & 307 & -1 & N.A. & N.A. & N.A. \\
\hline 10 & CT2-b & 0.4 & -121 & 32 & 16 & 0.7 & 0.2 & N.A. \\
\hline 12 & CT2-b & 0.4 & -372 & 29 & 1,646 & 0 & N.A. & N.A. \\
\hline
\end{tabular}

Note: SFi represent stresses in i axes and SMi represent moments in i axes 